\title{
Logistics and Supply Chain Management Efficiency Strategy for Ghana's Mining Industry
}

\author{
Qu Yaping and Mary Bossman
}

\section{ABSTRACT}

The invaluable contribution of the mining industry in any country's economy is widely acclaimed and thus not far-fetched. In as much as the mining industry contributes hugely to economic and social growth, its operations are characterized by complex supply chain processes that are relatively capital and cost intensive, and technologically sophisticated to manage. Unfortunately, firms in the mining industry especially for developing countries tend to focus more on procuring modernized equipment and technologies to carry out the complex processes of mining operations to the detriment of applying logistics optimization models.

This research project therefore seeks to analyze the logistics and supply chain operations of mining companies in Ghana, identify the challenges and inefficiencies associated with these operations and their underlying causes, and recommend logistics and supply chain management design, modelling and analysis tools to optimize. With the help of secondary data collected from books, journals, which were further depicted in graphs and tables, the Microsoft Excel Solvers for Vehicle Routing Problem (VRP, Version 3.42), with an embedded Bing Map Key License was used to illustrate and derive optimal solutions for the transportation efficiency of mining firms in Ghana.

The study revealed that the mining industry in Ghana is confronted with supply chain issues like poor road networks in mining communities, variable lead time and exchange rate, strict governmental laws, violent clashes over land royalties, high transport cost due to bad roads, unreliable lead times (caused by port delays), unavailability of local suppliers of international standards, and policy restrictions as the main challenges to supply chain. Clearly, the policy implication emanating from this study is that mining firms in partnership with transport services firms in Ghana must adopt an efficient service delivery and optimal transportation cost reduction strategies, which is designed with the Vehicle Routing Problem Optimization Model in order to benefit mutually in gaining competitive advantage.

Keywords: Logistics Management, Supply Chain Management, Strategy, Efficiency, Mining.

\section{INTRODUCTION}

Firms in the mining industry especially for developing countries lack the appropriate models to optimize their logistic operations, mainly because they tend to focus more on procuring modernized equipment and technologies to carry out the already complex processes of the mining industry. For instance, third party logistics service providers sometimes find it a hurdle to forecast their supply chains due to supply chain risk and uncertainty [65]. For this reason, most mining companies outsource their logistics and transport operations to third party (3PL) logistics operators; whose profit mindedness stifle the integrated efficiency, optimal cost and profitability targets of mining companies. The quest to meet the dynamic and myriad service targets of clients coupled with the need to remain in business, have
Submitted : February 25, 2021

Published : April 26, 2021

ISSN: $2507-1076$

DOI: $10.24018 /$ ejbmr.2021.6.2.779

Qu Yaping

Jiangsu University, School of Management, China.

(e-mail: yapingqu0319@gmail.com) Mary Bossman*

Jiangsu University, School of Management, China.

(e-mail: bossmanmary10@yahoo.com)

*Corresponding Author augmented the level of competition in the logistics services industry. [39] attributed the complexity of the transportation business to the unpredictable increase in business on some trade lanes and the laws of the importing country. By necessary implication, transportation careers and service providers now have to compete openly and aggressively against new entrant, existing carriers and competition from other modes of transport [62].

Ghana as a state is endowed with lots of natural resources, which has helped generate critical revenue for the state. Mining in Ghana is historically important and well documented as seen in the country's colonial name "gold coast": this is an indication of the mining industry to the Ghanaian economy [1]. In the first documentation gold production in Ghana, there is a long-standing tradition of 80 million ounces of gold produced between 1493 and 1997 [31]. 
Around this same time, Ghana contributed about $36 \%$ of the world's gold production there by being the second largest gold producer after south Africa in 1999. In spite of these great economic potentials, the output of mining has been on a decline with production being the worst [4]. For four decades up to the 1980's there was no new mine in Ghana: this according to [8] is a result of a cluster of challenges faced by investors in the mining sector. These challenges are classified into economic, legal, financial, and institutional modus operandi of the Ghanaian mining industry. In the words of [34], "Across Africa, in countries with rich minerals reserves and barren economies... miners use primitive methods of extraction with pick axes, mercury, and the strength of their arms". This situation is true to Ghana as over 30,000 Ghanaians are employed to engage in small-scale mining through primitive methods. The large-scale mining sector on the other hand uses highly mechanized equipment and thus employ few highly skilled individuals. The small and large-scale miners are the two main players of the mining industry in Ghana. However, large-scale mining companies are dominant and have more competitive advantage through a relatively stable and value creating supply chain. The major gold mining companies in Ghana includes Gold Fields Ghana limited, Anglo gold Ashanti, Newmont Ghana gold limited, Redback Mining Ltd (Chirano mines) and Central Africa Gold among others. Ghana's bauxite is mined by only Ghana bauxite company limited (GBC) in Awaso and Manganese company limited (MCL) is also solely in charge of bauxite mines in Nsuta-Wassa.

Ghana is so rich in terms of minerals such as bauxite, gold and among others however, there is lack of infrastructure to extract these minerals and export them in large quantity. One of the most challenging situations managers encounter is how to best use limited resources in the most optimal way possible; thus, minimizing cost whilst maximizing profit and not compromising the quality of service. Mismanagement of resources in the transportation of products can result in in the bankruptcy of a company whose transportation cost contributes a significant percentage of then overall operating cost. This shortcoming is either due to a truck breakdown or a halted mining activity at the mining sites. Also, when trucks breakdown in transit to some or all mining sites, it takes about 2 days or more for the product to be delivered to their required destination ports and that means no work done for such trucks during the breakdown periods.

Meanwhile, transportation cost in companies has great impact on their overall performances. Several researchers have revealed that there is a correlation between transportation expenses and business changes. According to [2], the major supply chain challenges found to be facing the mining sector in Obuasi include supply of low quality products, unreliable or variable lead times, non-availability of local firms of international standard, fluctuation in gold prices on the international market, high transportation cost and violence and sporadic attack from the communities. Logistics related issues include, inter alia, variable lead times, transportation challenges arising from poor road networks and limited capacity of local suppliers (World Bank, 2012). Out of 155 countries worldwide, Ghana rates 108th position on the Logistics Performance Index 2012 [43]. Currently, transportation of bauxite and several other minerals in Ghana are done solely by road contributing to $98 \%$ of freight carriage by road [43]. The rail lines of Ghana are in deplorable condition such that it is impossible for use as a mode of transporting bauxite. This factor has contributed to the enormous cost incurred by Ghana Bauxite Company when transporting bauxite from their mining sites to the Tema and Takoradi Ports of Ghana [32].

This research project ultimately aims to analyze the logistics and supply chain operations of mining companies in Ghana, identify the challenges and inefficiencies associated with these operations and their underlying causes, and recommend logistics and supply chain management design, modelling and analysis tools to optimize operations of Ghana's mining industry and ensure increasing profitability and cost efficiencies. Specifically, the research seeks to analyze the logistics and supply chain operations of Mining Companies in Ghana. Then identify the logistics and supply chain management challenges, inefficiencies and their underlying causes and finally recommend strategic logistics and supply chain management design, modelling and analysis tools for the optimal logistics operations and the superior performance of Ghana's Mining Industry.

\section{LITERATURE REVIEW}

The global mining industry has, been described as one of the largest with its most powerful and influential companies scattered all over both developed and developing countries of the world [60]. The industry is interconnected as natural resources are distributed across different jurisdictions of the world [27]; it is therefore important for research to focus on exploring and how to lump all these companies in the global mining sector possibly through an internet of things (IOT) approach to ensure mutual benefits. According to recent mining statistics and facts, the top 40 organizations which are the main movers and shakers of the whole industry made a revenue of more than 600 billion US dollars in 2017 and has been on a rollercoaster ride till date; hence the mining industry is a very essential pivot of the world's economic growth [29]. It is however critical to note that, this revenue in 2017 is $10 \%$ less than the previous year. [29] also reported that, world top five mining companies in terms of revenue in 2018 were UK-based. United states have also been phenomenal as it has created 621,00 jobs with a gross output of 288 billion US dollars as of 2017.

[10] analysis the processes involved in mining and its value chain: from deposits to mines and from the mines to mining value chain. He categorized the steps into pitting, opencast, underground and opencast. The entire mining value chain also consists a chain of critical activities which [29] further classifies under four stages which are mining, processing, refining, and fabrication. The activity or stage of mining involves getting the ore or the primary product (runof mine ores and washed appropriately sized concentrates). The second stage is processing which involves converting the concentrate from the first stage into required tonnage or into the immediate product: mattes/slags/ bulk chemicals to Ferro alloys and pure metals. The refining stage simply means converting the goods into a refined product to meet the demand of both small and huge companies (that is steel and alloys to worked shapes). The final stage is fabrication where 
a final product is manufactured for sale. It must be mentioned however that all of these stages are on the average highly capital intensive.

\section{Methodology}

Four (4) research philosophies have been extensively espoused in management research literature; Positivism, Realism, Interpretivism and pragmatism, which are further sub-categorized into Ontological, Epistemological and Axiological premises [65]. See Table I and Table II. The philosophical commitments of researchers most definitely influence the methodology applied in conducting their research projects, and how they interpret findings. Some of these possible influencing factors include as the individual's mental model, his worldview, different perception, many beliefs, and attitudes related to the perception of reality [63]. Interpretivist, ontological and axiological research philosophies form the main basis for this research project. The logistics and supply chain management skills, tools and techniques acquired over the years have shaped my perception and understanding of the underlying causes of the inefficiencies in logistics management operations. Thus, this definitely influenced my interpretation of challenges of firms in the mining industry. The inefficiencies identified after exploring the supply chain processes of firms in Ghana's mining industry also influenced the transport optimization modelling strategy recommended for enhancing the efficiency of value chain processes. [65] explained these philosophies as follows; the Interpretivist philosophers believe that configuration of societies and the activities they undertake is impossible without the active role of human beings. In the same vein, Ontology philosophers cling to the idea that personal values that relate to a particular subject of study influence the outcome of the study.

Finally, Axiological research philosophy associates the choices, values and judgment of researchers to the way the conduct research.

The deductive, inductive, qualitative and quantitative research approach were the mainstay of theorizing and interpreting the findings of this research project. Deductive approach to business research involves the application of existing theories in the context of real world scenarios in order to test and assess their validity, whiles inductive approach seek to establish theories that are derived from empirical observations of real world [19]. This project examined exiting theories, strategies and models for managing logistics and supply chain operations in order to determine the appropriate model to deploy as recommendation for players in the mining industry. This makes the study deductive in nature. Inductively, this study designed strategies and guides to policy formulation for both private and public agency players in Ghana's mining industry.

Moreover, in addition to applying models, coupled with statistical inferences and graphical representations of the secondary data survey, this research project is deemed qualitative and quantitative. Qualitative research explores the meaning individuals or groups ascribe to a social or human problem. Quantitative research on the flip side test theories by examining variables relationships [18].
The research design and tactics is the most technical part of the research project where the entire research functionality is mined. This is guided by the research objectives and philosophical commitment of the researcher. More specifically, the research design is concerned with the overall plan of your research, whiles research tactics emphasize the details of how to collect and analyze particular kinds of information [57]. This section presents the research purpose, research strategy, study population and sampling procedures, data sources and collection procedures, and data analysis and presentation models, with clear justification of their credibility.

\section{A. Research Purpose}

This study is purposed at analyzing the logistics and supply chain operations of mining companies in Ghana, identify the challenges and inefficiencies associated with these operations and their underlying causes, and recommend logistics and supply chain management design, modelling and analysis tools to optimize operations of Ghana's mining industry and ensure increasing profitability and cost efficiencies.

\section{B. Research Strategy}

This research depended on the cases of a few firms in Ghana's mining industry to understand the main value chain activities of the mining sector with much emphasis on the management of their logistics and transport processes. It also unraveled the causes of the evident inefficiencies engulfing the selected firms and discuss the way forward. In essence, therefore, the study is exploratory and explanatory in nature. According to Kumar [49], explanatory research highlights why and how there is a relationship between two aspects of a situations or phenomenon. Whiles exploratory research ventures into research areas where little is known or verifies the feasibility of undertaking a particular research study.

\section{Study Population and Sampling Procedures}

All mining firms and their logistics, transport and supply chain activities in Ghana forms the population of this research project, including the activities of their value chain partners. All possible players in a group within the largest possible jurisdiction, and within which a specific subject matter relevant to a research topic can be discussed is referred to as the population of the research [52].

However, three major mining firms in Ghana; namely Newmont Ghana Gold limited, Anglo Gold Ashante, and Gold fields limited were selected purposively for generating data for analyzing the logistic and transport efficiency and improvement strategies being applied in the mining industry. These firms were selected because they operate on a relatively larger scale as compared with other small-scale mining firms. Besides, data is available for these firms to facilitate result analysis and model application. Purposive sampling connotes the idea of selecting particular subjects that can provide in-depth knowledge on the subject matter of the research project [50].

\section{Data Sources and Collection Procedures}

The chief source of compiling data for the analytical and modeling procedures of this research project was mainly documentary and survey-based secondary. Crucial 
parameters for assessing the efficiency of transporting mineral products to the two major ports in Ghana from specified mining sites were not eluded. The secondary data were specifically derived from organizational notices, financial statements, website, annual and general meeting reports, books, journal articles, media accounts, newspapers and government publications.

First, frequencies, tables and graphs were used to represent findings as a means of further interpretation and easy understanding by readers. Existing logistics and supply chain management models and information technologies were also applied as a guide to generate and analyze relevant secondary data, which consequently informed the best optimal path to minimizing the inefficiencies bedeviling the three selected firms.

Mathematical models formulate any given problem and direct the means of solving them [59]. Thus, a wrong representation will produce a wrong solution to any given problem. It is normally in a form of equation and in this scenario it comprises the objective function of the equation, decision variables and constraints. The Objective Function is what the model is to optimize. This function is either to be minimized or maximized. In the case of cost the objective function is to be minimized and vice-versa in the case of profit. It is considered feasible if it satisfies the corresponding constraints and these constraints could be equalities or inequalities. Variables are quantities that can be changed in order to produce the optimal value of the objective function (Thornburg). Constraints, just like the name suggests, are limitations on the values of the variables.

For this research project, a Vehicle Routing Problem (VRP) that considers vehicle capacities, number trips required, the time window allowed by customers, customer demand, and the distance between mining sites and ports, as presented in [49], constitute the main optimization tool that assisted in revitalizing the logistics activities of firms in Ghana's mining industry.

\section{DATA ANALYSIS}

A. The Logistics and Supply Chain Efficiency and the Competitive Position of Firms in Ghana's Mining Industry

The logistics and supply chain management function of Ghana's mining industry is doing well, and organizations are not at a much of a competitive disadvantage. Being ranked the 10th largest producer of gold and generating the revenues stated above suggests there is an enabling environment to thrive globally. But to achieve this global competitiveness, the supply chain must be analyzed to fish out inefficiencies and replace them with value- creating factors or components. This probably why [27] points out that, the more companies become aware of best practices in supply chain, the more they try to enhance supplier relationships to create overall value and get competitive advantage. Ghana does international trade by exporting products from mining and this according [52] is a basis for competitive advantage. The industry looks open especially for large-scale mining companies like Ghana bauxite company, Newmont gold Ghana limited, Gold fields Ghana limited and Anglo gold Ashanti. Hence there is a need to focus more on analyzing the entire supply chain to identify factors that create value and enhance it while eliminating factors that breaks the supply chain. For example, while transporting gold from the mines to factory for production, lead time is very critical hence maintenance of trucks must be a priority. In addressing issues of bad roads, the critical path method can be used to determine which route is ideal to deliver goods just in time. Companies can also engage in corporate social responsibility activities like constructing roads which will not only develop the community but also optimize supply chain: benefits are dyadic.

\section{B. Recommended Optimal Logistics and Supply Chain Cost Management Efficiency for Mining Firms in Ghana}

Although logistics flow systems may be complex and interrelated in reality, some simple cost function analysis may be applied in solving optimal cost and customer service target problems. In competitive terms, cost is supposed to be a value added activity which may be offset by increase in sale volume and the consequential increase in profit margin. Therefore, cost efficiency of organization must not be compared on the basis of lowest possible cost, but the superiority of the value created as a result of the expenditure. This section activates the proposed linear programming approach to logistics transportation cost optimization, as well as logistics customer service improvement strategy for mining firms in Ghana. The section encapsulates a description of the derived hypothetical dataset for the logistics and transport operations of a typical mining firm in Ghana; the formulation of the optimization model parameters, decision variables and objective function; and strategizing for optimal customer service performance.

\section{Description of the logistics, transport, and supply system of mining firms in Ghana}

The logistics operations of mining firms in Ghana are mainly outsourced to third party logistics services providers. Therefore, the responsibility of ensuring cost efficiency and customer satisfaction in the process is shared by all value chain players. There are exactly two ports that are to be supplied, Tema Port and Takoradi Port. The distance between the mining sites and the ports are very long and therefore enables each vehicle to deliver to their destination ports at most twice. It must be noted that, due to the very congested nature of both ports, vehicles must always arrive at certain times of the day in order to avoid time wasted at the port and also avoid heavy traffic congestion. Sometimes, vehicles breakdown on the way and when that happens an empty vehicle has to be sent to deliver the goods to the required destination. The vehicles have specified carrying capacity and they must never carry less or more than the specific quantity. The assumption is that all vehicles are similar and have similar capacity [56]. The roads leading to these sites also threaten the durability of these vehicles due to its bad condition and so even though a third trip can be made, it is not an option. The objective function therefore is to minimize the cost of haulage of mineral products such as bauxites from three main mining sites to the two ports, subjects to a limited number of vehicles and their carrying capacity of goods. That is, identifying the best quantities of products that must be shipped from various mining sites to various ports based on the carrying capacities of logistics firms and the demands of customers, in other to minimize the 
total transportation cost of delivery and the fleet cost which is associated with the loading and distance.

Ghana Bauxite Company (GBC) mines and exports bauxite to countries such as China, USA and several countries in Europe. GBC has had to seek transportation services from several logistics companies over the years. Madison Ghana Company Limited is a logistics/transportation company birthed in 2004. It is a private company owned by the Kyere-Mensah and the Agriculture Development Bank of Ghana. They are specialized in the hauling of bauxite by road from three bauxite deposits in Ghana, Awaso site, Kibi site and
Nyinahin site to the two major ports in Ghana. Madison Company Limited owns about 30 trucks that haul bauxite and other mineral products from these three mining sites. Averagely, these trucks work 20 days in a month with holidays included. International customers are served through two major seaports, Tema port and Takoradi port.

Let us consider the following illustration: Let $o, 1, \ldots 2, d$ be nodes where $o$ and $d$ are the same nodes, for sets of 2 customers. Customer demands, service times, time windows of the customers, vehicle compartment capacities, distances between nodes, cost of travel and loading are shown from Table I to IV for the purpose of this illustration.

TABLE I: VRP MicRoSOFT EXCEL SOLVER CONSOLE WITH EMBEDDED BING MAP

\begin{tabular}{ccc}
\hline Sequence & Parameter & Value \\
\hline 0. Optional -GIS License & Bing MAPS Keys & An8 \\
1. Location & Number of Mining Sites & 3 \\
2. Distances & Number of customers & 2 \\
& Distance Computation method & Bing MAPS driving distances (km) \\
& Duration Computation method & Bing MAPS driving durations \\
& Bing MAPS route type & Fastest \\
3. Vehicles & Average Vehicle speed & 80 \\
4. Solution & Number of vehicle types & \\
& Do the vehicles return to their depot(s)? & yes- only once at the end \\
& Time window type & Hard \\
& Backhauls? & No \\
5. Optional-Visualization & Visualization background & Bing Maps \\
& Location labels & Bank \\
6. Solver & Warm start? & Yes \\
& Show progress on the status bar? & Yes \\
& CPU time limit (seconds) & 60 \\
\hline
\end{tabular}

TABLE II: DisTANCE BETWEEN Mining SiTE (I) AND CUSTOMERS AND OTHER Mining SiTE (J)

\begin{tabular}{cccc}
\hline From & To & Distance & Duration \\
\hline Awaso Mining Site & Awaso Mining Site & 0 & $0: 00$ \\
Awaso Mining Site & Kibi Mining Site & 270.96 & $5: 17$ \\
Awaso Mining Site & Nyinahin Mining Site & 62.99 & $1: 35$ \\
Awaso Mining Site & Tema Customers & 355.42 & $6: 52$ \\
Awaso Mining Site & Tarkoradi Customers & 242.08 & $4: 38$ \\
Kibi Mining Site & Awaso Mining Site & 271.07 & $5: 17$ \\
Kibi Mining Site & Kibi Mining Site & 0 & $0: 00$ \\
Kibi Mining Site & Nyinahin Mining Site & 231.65 & $4: 27$ \\
Kibi Mining Site & Tema Customers & 108.03 & $2: 07$ \\
Kibi Mining Site & Tarkoradi Customers & 273.75 & $5: 29$ \\
Nyinahin Mining Site & Awaso Mining Site & 63.01 & $1: 34$ \\
Nyinahin Mining Site & Kibi Mining Site & 229.89 & $4: 27$ \\
Nyinahin Mining Site & Nyinahin Mining Site & 0 & $0: 00$ \\
Nyinahin Mining Site & Tema Customers & 330.68 & $6: 19$ \\
Nyinahin Mining Site & Tarkoradi Customers & 293.41 & $5: 53$ \\
Tema Customers & Awaso Mining Site & 363.33 & $6: 51$ \\
Tema Customers & Kibi Mining Site & 115.35 & $2: 07$ \\
Tema Customers & Nyinahin Mining Site & 336.65 & $6: 21$ \\
Tema Customers & Tema Customers & 0 & $0: 00$ \\
Tema Customers & Tarkoradi Customers & 246.38 & $5: 03$ \\
Tarkoradi Customers & Awaso Mining Site & 242.09 & $4: 40$ \\
Tarkoradi Customers & Kibi Mining Site & 272.81 & $5: 32$ \\
Tarkoradi Customers & Nyinahin Mining Site & 293.39 & $5: 54$ \\
Tarkoradi Customers & Tema Customers & 238.24 & $5: 11$ \\
Tarkoradi Customers & Tarkoradi Customers & 0 & $0: 00$ \\
\hline & & &
\end{tabular}

TABLE III: The LocAtion, Time Window, Customer Demand, SuPPly CAPACITY AND PROFITABILITY FOR SERVING EACH Mining Site AND

\begin{tabular}{|c|c|c|c|c|c|c|c|c|c|c|}
\hline \multicolumn{11}{|c|}{ CUSTOMER } \\
\hline Starting depot & Address & Latitude(y) & Longitude(x) & $\begin{array}{c}\text { Tume } \\
\text { window start }\end{array}$ & $\begin{array}{c}\text { Tume } \\
\text { window end }\end{array}$ & $\begin{array}{c}\text { Must be } \\
\text { visited }\end{array}$ & $\begin{array}{c}\text { Service } \\
\text { time }\end{array}$ & $\begin{array}{l}\text { Pickup } \\
\text { amount }\end{array}$ & $\begin{array}{r}\text { Delivery } \\
\text { amount }\end{array}$ & Profit \\
\hline $\begin{array}{c}\text { Awaso } \\
\text { Mining Site }\end{array}$ & $\begin{array}{c}\text { Awaso, } \\
\text { Ghana }\end{array}$ & 6.2333298 & -2.26667 & 0:00 & $23: 59$ & $\begin{array}{l}\text { Starting } \\
\text { location }\end{array}$ & 0:00 & 0 & 0 & 0 \\
\hline $\begin{array}{l}\text { Kibi Mining } \\
\text { Site }\end{array}$ & Kibi, Ghana & 6.1654201 & -0.55666 & 0:00 & $23: 59$ & $\begin{array}{l}\text { Starting } \\
\text { location }\end{array}$ & 0:00 & 0 & 0 & 0 \\
\hline $\begin{array}{c}\text { Nyinahin } \\
\text { Mining Site }\end{array}$ & $\begin{array}{l}\text { Nyinahin, } \\
\text { Ghana }\end{array}$ & 6.5994101 & -2.1159899 & 0:00 & $23: 59$ & $\begin{array}{l}\text { Starting } \\
\text { location }\end{array}$ & 0:00 & 0 & 0 & 0 \\
\hline $\begin{array}{c}\text { Tema } \\
\text { Customers }\end{array}$ & Tema, Ghana & 5.6177702 & -0.01681 & 0:00 & $23: 59$ & $\begin{array}{l}\text { Must be } \\
\text { visited }\end{array}$ & 0:00 & 100 & 300 & 50000 \\
\hline $\begin{array}{l}\text { Tarkoradi } \\
\text { Customers }\end{array}$ & $\begin{array}{c}\text { Tarkoradi, } \\
\text { Ghana }\end{array}$ & 4.935596 & -1.7281801 & 0:00 & $23: 59$ & $\begin{array}{l}\text { Must be } \\
\text { visited }\end{array}$ & 0:00 & 85 & 250 & 55000 \\
\hline
\end{tabular}


European Journal of Business and Management Research www.ejbmr.org

TABLE IV: THE NUMBER OF VEHICLES AND THEIR CAPACITIES, COST VARIABLES AND TIME LIMITS FOR EACH MINING SITES

\begin{tabular}{|c|c|c|c|c|c|c|c|c|c|c|}
\hline Starting depot & $\begin{array}{l}\text { Vehicle } \\
\text { type }\end{array}$ & Capacity & $\begin{array}{l}\text { Fixed cost } \\
\text { per trip }\end{array}$ & $\begin{array}{l}\text { Cost per } \\
\text { unit } \\
\text { distance }\end{array}$ & $\begin{array}{l}\text { Duration } \\
\text { multiplier }\end{array}$ & $\begin{array}{c}\text { Distance } \\
\text { limit }\end{array}$ & $\begin{array}{l}\text { work } \\
\text { start } \\
\text { time }\end{array}$ & $\begin{array}{c}\text { Driving } \\
\text { time } \\
\text { limit }\end{array}$ & $\begin{array}{c}\text { working } \\
\text { time } \\
\text { limit }\end{array}$ & Return depot \\
\hline $\begin{array}{l}\text { Awaso Mining } \\
\text { Site }\end{array}$ & $\begin{array}{c}\text { Man } \\
\text { Diesel }\end{array}$ & 100 & 150 & 25 & 1 & 600 & $8: 00$ & $10: 00$ & $10: 00$ & Awaso Mining Site \\
\hline $\begin{array}{l}\text { Kibi Mining } \\
\text { Site }\end{array}$ & $\begin{array}{c}\text { Man } \\
\text { Diesel }\end{array}$ & 100 & 150 & 25 & 1 & 600 & $8: 00$ & $9: 00$ & $10: 00$ & Kibi Mining Site \\
\hline $\begin{array}{c}\text { Nyinahin } \\
\text { Mining Site }\end{array}$ & $\begin{array}{c}\text { Man } \\
\text { Diesel }\end{array}$ & 100 & 150 & 25 & 1 & 600 & $8: 00$ & $9: 00$ & $10: 00$ & Nyinahin Mining Site \\
\hline
\end{tabular}

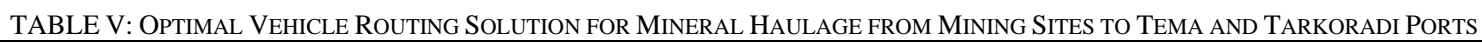

\begin{tabular}{|c|c|c|c|c|c|c|c|c|}
\hline $\begin{array}{c}\text { Total net profit: } \\
\text { Vehicle: }\end{array}$ & $\begin{array}{c}87011.2 \\
\text { V1 } \\
\end{array}$ & Stops & 2 & Net profit: & 42745.65 & & & \\
\hline Stop count & Location Name & $\begin{array}{l}\text { Distance } \\
\text { travelled }\end{array}$ & $\begin{array}{c}\text { Driving } \\
\text { time }\end{array}$ & $\begin{array}{c}\text { Arrival } \\
\text { time }\end{array}$ & $\begin{array}{c}\text { Departure } \\
\text { time }\end{array}$ & Working time & $\begin{array}{c}\text { Profit } \\
\text { collected }\end{array}$ & Load \\
\hline 0 & Awaso Mining Site & 0:00 & 0:00 & & 8:00 & $0: 00$ & 0 & 250 \\
\hline 1 & Takoradi Customers & 242.08 & $4: 38$ & $12: 38$ & $12: 38$ & $4: 38$ & 55000 & 85 \\
\hline 2 & Awaso Mining Site & 484.17 & $9: 18$ & $17: 18$ & & $9: 18$ & 55000 & 0 \\
\hline Vehicle: & V11 & Stops & 2 & Net profit: & 44265.55 & & & \\
\hline Stop count & Location Name & $\begin{array}{l}\text { Distance } \\
\text { travelled }\end{array}$ & $\begin{array}{c}\text { Driving } \\
\text { time }\end{array}$ & $\begin{array}{c}\text { Arrival } \\
\text { time }\end{array}$ & $\begin{array}{l}\text { Departure } \\
\text { time }\end{array}$ & Working time & $\begin{array}{l}\text { Profit } \\
\text { collected }\end{array}$ & Load \\
\hline 0 & Awaso Mining Site & 0:00 & 0:00 & & 8:00 & 0:00 & 0 & 300 \\
\hline 1 & Takoradi Customers & 108.03 & 2:07 & $10: 07$ & 10:07 & 2:07 & 55000 & 100 \\
\hline 2 & Awaso Mining Site & 223.38 & $4: 14$ & $12: 14$ & & $4: 14$ & 50000 & 0 \\
\hline
\end{tabular}

2. Formulation of the vehicle routing optimization model parameters

The following sets are adopted to formulate the logistics distribution problem in Ghana's mining industry. Let $\mathrm{G}(\mathrm{N}, \mathrm{A})$ be a graph with $\mathrm{N}$ as set of vertices and $\mathrm{A}$ as a set of $\operatorname{arcs}(i, j)$ which represent the links between the depot and among the seaports. The details of each variable, set and parameter are shown below:

$N=$

$\{o, d, 1,2,3, \ldots, n\}$ be a node set (o is mining site and $\boldsymbol{d}$ is sea port),

$N^{*}=N \backslash\{o, d\}, A(i, j): i, j \in N, i \neq j$ be the arc set,

$K=\{1,2,3, \ldots, V\}$ be a set of vehicles,

$P=\{1,2,3, \ldots, p\}$ be a set of mineral products,

$T=\{1,2,3 \ldots, t\}$ be a set of vehicle compartments,

$R=\{1,2,3, \ldots, r\}$ be a set of trips.

$d s_{i, j}=$ be a distance between ports $i$ and $j$,

$t_{i, j}=$ be a time (hour) from port $i$ to $j$

(e.g. $t_{i, j}=\frac{d s_{i, j}}{v}$, where v means traveling speed of each vehicle),

$d m_{i, p}=$ be the demand of the port $i$ in mineral product $p$,

$C p_{k, t}=$ be the capacity of a compartment $t$ in the vehicle $k$, (11)

$M=$ be an arbitrary big number (such as $M=\Sigma_{k} \Sigma_{t} \Sigma_{C p_{k, t}}$ )

$T C_{k}=$ be the fixed cost per kilometer of running of each vehicle,
$L C_{k}=$

be the cost per unit vehicle travel per unit of load of mineral product,

$s_{i}=$ be a service time at port $i$,

$a_{i}=$ be the lower bound of soft time window for the port $i,(16)$

$b_{i}=$ be the upper bound of soft time window for the port $i,(17)$

$L B_{i}=$ be the lower bound of hard time window for the port $i,(18)$

$U B_{i}$ be the upper bound of hard time window for the port $i,(19)$

$P_{l}=$ be penalty cost per hour for the earliness,

$P_{u}=$ be penalty cost per hour for the lateness.

In essence therefore, the main decision variables for the routing problem include:

$X_{k, r, i, j}=$

$\left\{\begin{array}{c}1, \text { if vehicle } k \text { travels directly from node }(i) \text { to }(j) \text { in trip }(r) \\ 0, \text { otherwise, }\end{array}\right.$

And

$U_{k, r, t, p}=$

$\{1$, if a vehicle $k$ delivers a product $p$ in a compartment $t$ in a trip $r$; 0 , otherwise,

where

$X T_{k, r, i, j, p}=$ is the quantity of mineral product $\mathrm{p}$ to be transported from mining site $\mathrm{i}$ to port $\mathrm{j}$ by vehicle $\mathrm{k}$ in trip $\mathrm{r}$; $X L_{k, r, i, p}=$ is the quantity of mineral product $\mathrm{p}$ to be disposed at port $\mathrm{i}$ by vehicle $\mathrm{k}$ in trip $\mathrm{r}$;

$W_{k, r, j}=$ is the starting time of service in port $\mathrm{i}$ by the vehicle $\mathrm{k}$ in trip $\mathrm{r}$;

$W l_{k, r, i}=\max \left\{a_{i}-W_{k, r, j}, 0\right\}$ is the violation degree of a lower bound of soft time window;

$W u_{k, r, i}=\max \left\{W_{k, r, j}-b_{i}, 0\right\}$ the degree to which an upper bound of soft time window.

To find optimal solutions for the vehicle routing problem, the objective function consists of minimizing two components; first the traveling cost which involves the 
distances covered by vehicles and the fixed costs per unit distance, as well as the fleet cost which is associated with the loading and distance. This is mathematically formulated using the above presented parameters as follows:

$$
\operatorname{Min}\left\{\sum_{k} \sum_{r} \sum_{(i, j) \in A} d s_{i, j} X_{k, r, i, j} T C_{k}+\sum_{k} \sum_{r} \sum_{p} \sum_{(i, j) \in A} d s_{i, j} X T_{k, r, i, j, p} L C_{k p}\right\}
$$

The constraints to this model are such that, first, the flow of a vehicle is conserved, where every vehicle starts only once at the mining site and no arc terminates at ports $(o)$, and every vehicle ends only once at the mining sites $(i)$ and no arc originates from ports $(d)$. Consequently, exactly one vehicle enters and leaves each port. Additionally, each port is serviced exactly once. Again, all customers must be assigned to at most one vehicle. More so, the model ensures

that the total quantity of mineral transported does not exceed the vehicle's capacity. Another constraint is that the sum of mineral quantities disposed at a port by all the vehicles must be equal to the demand for the mineral product $(p)$. The sum of quantities of mineral product to be transported by the vehicle to the port from the mining site node $(o)$ should in total be greater than the total sum of the demands at all customers. Moreover, the quantity of product transported to a port minus the mineral quantity disposed at that port must be equal to the quantity transported to the next customer by the vehicle. The entire vehicle compartment is dedicated to the mineral product hauled by the company. Finally, starting time of a service does not violate the given hard time window. These constraints are mathematically modeled below:

\section{Subject to;}

$\sum_{j} X_{k, r, i, j}-\sum_{j} X_{k, r, i, j}=\left\{\begin{array}{c}-1, i=0 ; \\ 1, i=d ; \\ 0, \text { otherwise }\end{array} \forall \in N, \forall k \in K, \forall r \in R\right.$,

$\sum_{k} \sum_{r} \sum_{j} X_{k, r, i, j}^{25}=1 ; \forall i \in N^{*}$,

$\sum_{j} X_{k, r, i, j} \leq 1 ; \forall i \in N^{*}, \forall k \in K, \forall r \in R$,

$\sum_{j \in N^{*}} X T_{k, r, o, j, p} \leq \sum_{t} U_{k, r, i, p} C p_{k, i} ; \forall k \in K, \forall r \in R, \forall p \in P$,

$\sum_{j} X L_{k, r, i, p}=d m_{i, p} ; \forall i \in N^{*}, \forall p \in P$,

$\sum_{k} \sum_{r} \sum_{j} X T_{k, r, i, j, p}=\sum_{j \in N^{*}} d m_{j, p} ; \forall i \in N^{*}, \forall p \in P$,

$\sum_{i} X T_{k, r, i, n, p}-X L_{k, r, n, p}=\sum_{j} X T_{k, r, i, j, p} ; \forall i \in N^{*}, \forall k \in K, \forall r \in R, \forall p \in$ $P$,

$X T_{k, r, i, j, p} \leq X_{k, r, i, j} M ; \forall i, j \in N, \forall k \in K, \forall r \in R, \forall p \in P$,

$X T_{k, r, i, d, p}=0 ; \forall i \in N^{*}, \forall k \in K, \forall r \in R, \forall p \in P$,

$X_{k, i, i}=0 ; \forall i \in N^{*}, \forall k \in K$,

$X_{k, o, d}=0 ; \forall k \in K$,

$\sum_{i} U_{k, r, i, p} \leq 1 ; \forall t \in N^{*}, \forall k \in K$.

$\left(W_{k, r, i}+t_{i, j}+W_{k, r, j}\right) X_{k, r, i, j} \leq 0 ; \forall i, j \in N, \forall k \in K, \forall r \in R$.

$W_{k, r, i}-W_{k, r, j}+\left(b_{i}+t_{i, j}+s_{i}-a_{j}\right) X_{k, r, i, j} \leq b_{i}-a_{j} ; \forall i, j \in N, \forall k \in$

$K, \forall r \in R$

$a_{i} \leq W_{k, r, i} \leq b_{i} ; \forall i \in N^{*}, \forall k \in K, \forall r \in R$
To incorporate soft time windows into the model for each node, the vehicle routing problem can then be modelled as follows:

$\operatorname{Min}\left\{\sum_{k} \sum_{r} \sum_{(i, j) \in A} d s_{i, j} X_{k, r, i, j} T C_{k}+\sum_{k} \sum_{r} \sum_{p} \sum_{(i, j) \in A} d s_{i, j} X T_{k, r, i j, p} L C_{k p}+\right.$ $\left.\sum_{k} \sum_{r} \sum_{i}\left(P l W l_{k, r, i}+P u W u_{k, r, i}\right)\right\}$

\section{Solution and results}

The above variables and parameters were coded in Microsoft Excel Solvers for Vehicle Routing Problems (Version 3.42), with an embedded Bing Map Key License. The optimal solution derived from over 200 iterations by the system is shown in Table $\mathrm{V}$ and visualized in Fig. 1 below.

Therefore, in order to maximize the quantities of bauxite required at each, achieve the minimal possible total transportation cost and obtain a total net profit of Ghc87,011.20, Madison Ghana Company Limited must ship about 85 Metric tons of bauxite from the Awaso mining site to the Takoradi Port and about 100 Metric tons of bauxite from the Kibi mining site to the Tema Port. However, no bauxite should be transported from the Awaso mining site to the Tema Port. Additionally, no bauxite should be hauled from the Kibi mining site and the Nyinahin mining site to the Takoradi Port. The above shipment route selection would ensure that mining companies can optimize their profitability notwithstanding the overwhelming demand for the customers that even exceeds the capacities of each vehicle available (Fig. 1).

The above illustration shows how mining firms in partnership with third party logistics service providers in Ghana can optimize their transportation cost whiles maximizing the total quantities of product demanded by customers across the world. It must be emphasized that it would not be always prudent to ship bauxite from some or all mining sites, depending on the various parameters considered above, such as the delivery cost, the capacity of mining sites and vehicles and the quantities demanded by customers at various locations. When the entire haulage operation is considered in this sense, then the lowest possible transportation cost would always be ensured, thus enhancing the efficiency of mining operations. That notwithstanding, much cost would be lost to transportation inefficiencies.

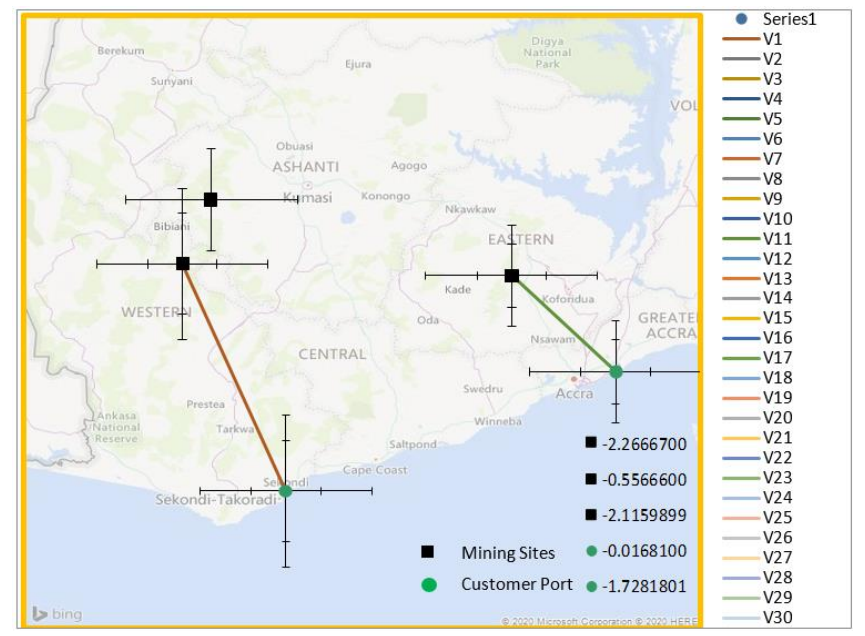

Fig. 1. A Map of the Vehicle Routing Problem and Solution for Mineral Haulage from Mining Sites to Tema and Tarkoradi Ports Source: Produced from Bing Map. 


\section{Logistics customer service analysis and improvement strategy}

Logistics customer service is one most strategic function in managing logistics services cost by accurately measuring the losses associated with serving particular customer, identify optimum performance levels, setting service variability targets and most importantly directing firms on planning service processes in order to achieve the best cost levels. Most Mining firms and Logistics service firms in Ghana fail to appreciate the relationship between logistics activities and their ramifications on cost and profitability. Although, the relationship between sales and service levels is veiled, research has proven that some level of variations in supplier sales occurs as a result of service level dwindles. Mathematically, the two-point method stipulates that for every market operated, the minimum customer service requirements must be achieved for survival. Meanwhile, there is also maximum service level beyond which sales may stifle. For instance, late deliveries generally imply increased in-transit inventory cost, increased transit time and customer dissatisfaction. The penalty for service failure is a reduction in orders from customers or lost sale.

\section{Measuring optimum service performance levels}

Mining firms and Logistics service firms in Ghana alike, can therefore leverage huge cost savings as a result of applying appropriate methodologies of measuring the optimal service levels that is required in the markets they serve. For instance, the service performance level of Ghana Bauxite Company can be calculated as follows. The company may typically collect data to this effect. Sales response rate $=0.10 \%$ change in revenue for a $1 \%$ change in the service level (fill rate). Trading margin $=\$ 0.55$ per case, Carrying cost $=35 \%$ per year, Annual sales through mining site $=90,000$ tons, Standard product cost $=\$ 20.00$, Demand standard deviation $=600$ tons over LT and Lead time $=2$ week.

\section{Solution:}

Find $\Delta P$.

$$
\Delta P=0.55 \times 0.0010 \times 90,000=\$ 49.50 \text { per year }
$$

Find $\Delta C$.

$$
\Delta C=0.35 \times 20.00 X 600 \Delta z=4200 \Delta z
$$

Set $\Delta P=\Delta C$ and solve for $\mathrm{z}$, i.e., $45.50 / 4200=\Delta \mathrm{z}$.

$$
\Delta z=0.011
$$

Therefore, in a normal distribution table, the change in $z$ correlates to about $82 \%$ optimal in-stock probability (customer service level) during the lead time.

\section{Measuring service variability}

Service variability also stems from uncertainties in the supply chain, which must be carefully analyzed to avoid uncalculated risk and cost. Hyman et al. (2006) defined service variability as changes in performance from one service encounter to another with the same service provider. Genichi Taguchi designed a loss function that helps to quantify the percentages of goods and services; such as order fill rates, delivery due dates and service qualities required by customers.

For example, suppose the delivery time for moving bauxites to their required destinations is 2 hours and a penalty of $\$ 5$ off the total bill is charged for products delivered more than 15 minutes late. Given an estimated delivery costs at $\$ 3$ but declines at the rate of $\$ 0.25$ for each minute deviation from target. How much variation should be allowed in the delivery service?

\section{Solution:}

Note that Total Cost $=$ Service Penalty cost + Service Delivery Cost

$$
L=k(y-m)^{2}
$$

where

$\mathrm{L}=$ loss per unit $(\$)$;

$\mathrm{y}=$ value of variable;

$\mathrm{m}=$ target service variable;

$\mathrm{k}=$ constant representing the importance of service variable.

First find k.

$$
\begin{gathered}
\Rightarrow 5=k(15-0)^{2} \\
k=\frac{5}{15^{2}}=\$ 0.022 \text { per minute }
\end{gathered}
$$

Next is to find variable $\mathrm{y}$ when $\mathrm{m}=0$.

Therefore,

$$
y-0=\frac{0.25}{2(0.022)}=5.68 \mathrm{~min}
$$

Hence, no more than 5.68 minutes should be allowed from the 2-hour delivery target in other to achieve the minimize cost.

\section{CONCLUSION}

Newmont Ghana Gold limited, Anglo Gold Ashanti, and Gold fields limited are the key players used as a basis for analysis in this study. It is found that Newmont Gold Ghana Limited sources all its raw materials locally with chain fencing link and barbed wire being the most locally sourced. In a bid to increase local supply, mining firms in Ghana generally include catering, transportation, healthcare, control systems, specialized services, mine construction and component manufacturers as categories of suppliers' but major activities are centered on specialized services and component manufacturers with frequencies and percentages of $48,30.4 \%$ and $25,15.8 \%$ respectively. While Newmont Gold Ghana limited prioritizes specialized services, it is number three on the list for suppliers while catering hits local supplier topmost priority with $42 \%$.

Irrespective of being the second largest producer of gold in Africa, Ghana still faces some critical supply chain challenges. Generally, the challenges of Ghana's mining industry can be grouped into production, commercial and environmental challenges. Specific supply chain challenges include poor road networks in mining communities, variable lead time and exchange rate, strict governmental laws, and violent clashes over land royalties lack of adequate raw 
materials for production. Cost management analysis and implementation is the first and most important step in reducing the overall cost of operation in an organization. The level of accuracy and profitability that may be achieved is hugely dependent upon the models and processes applied in analyzing cost centers. Some cost analysis models and principles applied by logistics service providers in Ghana are blue versus red ocean strategy, activity-based costing (ABC) system, total cost ownership, total quality management techniques and just-in-time principles, and transportation mode of performance criteria. The efficiency and effectiveness of managing supply chain using the mentioned models are important for the success of mining firms in Ghana. At the center of all these models and strategies must be competitive urge as it is an index that measures the superiority of a firm in an industry relative to its competitors which is determined by market share, customer loyalty, product quality, and price competitiveness.

In spite of all the prospects, the industry still battles with issues like the need for capacity, delegation of decisionmaking powers, the role of district assemblies, and the creation of concerted long-term development vision. For example, Newmont Ghana limited has legal agreements with the district assemblies to offer consultancy on project: how ever the districts assemblies have had serious capacity issues. In the same vein, Anglo gold Ashanti encounters setbacks in collaborating with more than 10 communities to work on a single project. To handle these issues, clear roles should be defined and all members of the supply chain must be empowered to enhance efficiency. Logistics and transportation cost optimization with customer service experience are business management functions that remains at the crux of achieving a sustained competitive edge in the freight transportation industry. Given the similar cost centers that competing firms have to manage, efficient service delivery coupled with optimal transportation cost is critical to overall supply chain profitability. Clearly, it is intrinsic for logistics and transport services firms to be strategically efficient and effective in managing their service and costs functions in order to benefit mutually in the competitive advantage they create for firms that contract them.

Supply chain managers in Ghana's mining industry are under constant pressure to churn-out strategies simultaneously and programs that are relatively efficient and customer-focused and finding the most innovative approaches to cut down cost, which will in turn leverage growth. Aside from this, managers must be able to take advantage of opportunities in their niche and business economic environment. This section concisely and precisely spells out some strategies managers in Ghanaian mining companies can adapt to enhance the efficiency of their supply chain.

\section{ACKNOWLEDGEMENT}

This paper is supported by the "Initial Funding for Advanced Talents at Jiangsu University (15JDG110) "and "Philosophy and Social Science Research Projects in Jiangsu Province (2016SJB630090)".

\section{REFERENCE}

[1] Agbesinyale, P. (2003). Ghana's Gold rush and regional development: The case of Wassa west district of Ghana. SPRING Research series, 44. University of Dortmund, Germany.

[2] Agyei, E.K., Sarpong, K.O., \& Anin, E.K. (2013). The Challenges of Supply Chain in the Gold Mining Sector of Obuasi Municipality of Ghana. International Journal of Business and Social Research (IJBSR), 3(9).

[3] Akabzaa, T. (2000). Boom and dislocation: the environmental and social impacts of mining in the Wassa west district in Ghana. TWN. Africa.

[4] Amponsah-Tawiah, K., \& Dartey-Baah, K. (2011). The Mining Industry in Ghana: A Blessing or a Curse. International Journal of Business and Social Science, 2(12).

[5] Anane, M. (2011). Lethal Cyanide Spill in Ghana outrages Ghana Mining Companies. Retrieved August 14, 2019, from http://www.ensnewswire.com/ens/july2006/2006-07-25.html.

[6] Anderson, Sweeney, Williams, Martin, \& Camm. (2012). An Introduction to Management Science. Ohio: Joe Sabatino.

[7] Anklesaria, J. (2008). Supply Chain Cost Management: AIM and DRIVE Process for Achieving Extra Ordinary Results. New York: Broadway.

[8] Aryee, B. (2001). Ghana Mining Sector: Its contribution to the National Economy. Resources Policy, 27, 61-75.

[9] Aydogan, C. G. (2010). Simultaneous Pick-up and Delivery Decision Support Systems. In G. Devlin, Decision Support Systems, Advances in (pp. 204-214). Croatia: ResearchGate.

[10] Badiu, F. V. (2004). A ginetic algorithms approach for solving the basic vehicle routing problem. Texas: ProQuest.

[11] Beck, J.C., Prosser, P., \& Selensky, E. (2003). Vehicle Routine and Job Scheduling: what's the difference? Proceedings of the 13th International Conference on Artificial Intelligence Planning and Scheduling.

[12] Bermúdez-Lugo, O. (2016). The Mineral Industry of Ghana. U.S. Geologicall Survey Minerals Yearbook-2013, 22.1-22.4.

[13] Boyle, B. (2009). Competitive Advantage in the Australian Coal industry, HiValue Strategies ACCA Client Briefing- No. 1. Australian Coal Alliance.

[14] Carter, C., \& Roger, D. (2008). A Framework of sustainable supply chain management: Moving toward new theory. International Journal of physical disttribution and logistics management, 360-387.

[15] Chopra, S., \& Sodhi, M. (2004). Managing risk to avoid supply-chain breakdown. MIT Sloan Management Review, 46, 52-61.

[16] Cornett, K. K. (2001). Algoritms Comparisons for a Vehicle Assignment Problem. Louisville: ProQuest.

[17] Coyle, J.J., Novack, R.A., Gibon, B., \& Bardi, E.J. (2010). Transportation: A Supply Chain Perspectives. Cengage Learning.

[18] Creswell, J.W. (2014). Research Design: Qualitative, Quantitative, and Mixed Methods Approaches. United Kingdom: SAGE.

[19] Crowther, D., \& Lauesen, L. M. (2017). Handbook of Research Methods in Corporate Social Responsibility. United Kingdom: Edward Elgar Publishing.

[20] Csiminga, D., Mangu, S., Iloiu, M., \& Marica, L. (2015). Creating Competitive Advantage in Coal Mining Industry in Romania: A New Challenge. Procedia Economics and Finance, 23, 428-433.

[21] David, F. A. (1997). Strategic Management (6th ed.). USA.

[22] Deya, P., \& Cheffib, W. (2013). Green Supply chain performance measurement using the analytic hierarchy process: a comparative analysis of manufacturing organizations. Production planning \& control, 24, 702-720.

[23] Dinitzen, H.B., \& Bohlbro, D. (2010). Value-Added Logistics in Supply Chain Management (1st ed.). Copenhagen: The Authors and Academica.

[24] Domingues, M.S.Q., Baptista, A.L.F., Diogo M.T. (2017). Engineering Complex Systems Applied to Risk Management in The Mining Industry. International Journal of Mining Science and Technology, 2095-2686. Retrieved from https://www.researchgate.net/deref/http\%3A\%2F\%2Fdx.doi.org\%2F $10.1016 \% 2$ Fj.ijmst.2017.05.007

[25] Dorin, I., Diaconescu, C., \& Topor, D.I. (2014). The Role of Mining in National Economies. International Journal of Academic Research in Accounting, Finance and Management Sciences, 4(3), 155-160.

[26] Erdogan, G. (2017). An open source Spreadsheet Solver for Vehicle Routing Problems. Computers and Operations Research, 62-72.

[27] Farahani, R., Rezapour, S., \& Kardar, L. (2011). Logistics Operation and Management: Concepts and Models. USA: Elsevier.

[28] Fawcett, S., Ellram, L., \& Ogden, J. (2014). Supply Chain Management from Vision to Implementation: An Integrative Approach. Pearson Higher Ed. 
[29] Garcia, J., Camus, J., Knight, \& P. (2010). Creating Competitive Advantage in Mining: An illustrative Comparation with the oil and gas industry, proceedings of the 4th International Conference on Mining innovation. Santiago, Chile: Publication office of the European union.

[30] Garengo, P., Biazo, S., \& Bittici, U. (2005). Performance measurement systems in SME's: A review for a research agenda. International journal of management reviews, 7, 25-47.

[31] Ghana Chamber of Mines. (1998). Annual Chamber of mines Report. Accra: Ghana chamber of mines.

[32] Ghana Chamber of Mines, g. (2005). The impact of mining on local economy. Annual report of the chamber of mines. Accra-Ghana: Ghana Chamber of mines.

[33] Ghana Minerals Commission, (2018). Statistical overview of Ghana's mining industry (1990-2004). Accra-Ghana: Ghana Minerals Commission.

[34] Harkinson, J. (2003). Illegal gold mining in Ghana shafts locals' health and the environment. grist magazine.

[35] Hillier, F. S. \& Lieberman, G. J. (2014). Introduction to Operations Research (10th ed.). Columbus, OH: McGraw Hill Higher Education.

[36] Hilson, G. (2001). Putting theory into Practice: How has the gold mining industry interpreted the concept of sustainable dvelopment? Mineral Resource Engineering, 10, 397-413.

[37] Hilson, G. (2004). Structural adjustment in Ghana: Assessing the impacts of mining-sector reform. African Affairs, 54-77.

[38] Hilson, G. (2005). Structural adjustment in Ghana: Assessing the impacts of mining sector reform. Africa Today, 51(2), 53-77.

[39] Hutt, M.D., \& Speh, T.W. (2012). Business Market Management: B2B. UK: Cengage Learning.

[40] Hyman, S. D., Lazio, T. J. W., Roy, S., Ray, P. S., Kassim, N. E., \& Neureuther, J. L. (2006). A New Radio Detection of the Transient Bursting Source. ApJ, 639, GCRT J1745-3009.

[41] International Council on Mining and Metal (ICMM). (2015). The Role of Mining in National Economies (2nd Edition). EuroMines. Retrieved from http://www.euromines.org/news/new-icmm-report-role-miningnational-economies.

[42] Jacobs-Blecha, Goetschalckx, M. and Charlotte. (1989). The Vehicle Routing Problem with Backhauls. European Journal of Operational Research, 39-51.

[43] Just, R.E. (2007). Mathematical Modeling in Agricultural Economics. Mathematical Models in Economics, II.

[44] Kabcome, P., \& Mouktonglang, T. (2015). Vehicle Routing Problem for Multiple Product Types, Compartments, and Trips with Soft Time Windows. International Journal of Mathematics and Mathematical Sciences. Retrieved from http://dx.doi.org/10.1155/2015/126754.

[45] Kapstein, E., \& Kim, R. (2011). The socio-economic impact of Newmont Gold Limited, Steward Redqueen. Stratcomm Africa, 8-9.

[46] Kauschke, K.-D. R. (2013). Transportation and logistics across Africa. Future prospects in Africa for the transportation \& logistics industry Africa gearing up, 43-48.

[47] Khurran, A., Rana, R., Rashid, M., \& Rahata, Q. (2017). Supply Chain Effectiveness and Efficiency- Case of Chinese Onyx Industry. International Journal of Research, 4, 1493-1500.

[48] Kumar, R. (2010). Research Methodology: A Step-by-Step Guide for Beginners. London: SAGE Publications.

[49] Kumar, R. (2014). Research Methodology: A Step-by-Step Guide for Beginners. United Kingdom: SAGE.

[50] Kusi-Sarpong, S., Sarkis, J., Wang, X., \& Filho, L. (2014). Sustainable Supply Chain Management Practices in Ghana's Mining Industry. Worcester: Foisie School of Business.

[51] Lancaster, G. (2007). Research Methods in Management: A Concise Introduction to Research in Management and London: Routledge Taylor \& Francis Group.

[52] Leedy, P., \& Ormod, J. (2001). Practical research: Planning and design (7th ed.). Upper Saddle River:NJ: Merrill Prentice Hall . Thousand Oaks: SAGE Publications.

[53] Lenzen, M., Murray, J., Sack, F., \& Wiedman, T. (2007). Shared producer and consumer responsibility- theory and practice. Ecological Economics, 61, 27-42.

[54] Li, X. (2015). Capacitated Vehicle Routing Problem with Time Windows A Case Study on Pickup of Dietary Products in Nonprofit Organization.

[55] Li, Y., zhoa, X., Shi, D., \& Li, X. (2014). Governance of sustainable supply chains in the fast fashion industry. European Management Journal, 35(5), 823-836.

[56] Loseke, D.R. (2012). Methodological Thinking: Basic Principles of Social Research Design. London: SAGE Publication.

[57] Lynch, C. (2010). Doing Your Research Project in Sports. London: SAGE.

[58] Magnus, E., \& Olof, L. (2019). Mining's contribution to national economies between 1996 and 2016. Mineral Economics, 223-250.
[59] Mahmudy, W. F. (2014). Improved simulated annealing for optimization of vehicle routing problem with time windows (VRPTW). KUSOR Journal, 109-116.

[60] Miao, Z. (2011). Discussion of Optimize Method of Fire Alarm Dispatching Based on Operation Research Principle. The 5th Conference on Performance-based Fire and Fire Protection Engineering (pp. 689-694). Langfang: Elsevier.

[61] Min, H. (2015). The Essentials of Supply Chain Management: New Concepts and Applications. FT Press.

[62] Monczka, R.M., Handfield, R.B., Giunipero, L.C., \& Patterson, J.L. (2015). Purchasing and Supply Chain Management. Boston: Cengage Learning.

[63] Nejman, J. M. (2015). UCT-based approach to Capacitated Vehicle Routing Problem. ResearchGate.

[64] Otchere, A., \& Annan, J. A. (2013). Achieving Competitive Advantage through Supply chain Integration in the Cocoa Industry: Acase study of Olam Ghana Limited and produce Buying company Limited. International Journal of Business and Social research (IJBSR), 3(2), 131-145.

[65] Saunders Mark (2009). Understanding research philosophies and approaches, University of Birmingham. 